\title{
О ВЛИЯНИИ СТРЕПТОМИЦИНА НА УСЛОВНОРЕФЛЕКТОРНУЮ ДЕЯТЕЛЬНОСТЬ БЕЛЫХ МЫШЕЙ
}

\section{В. М. Суи}

Стрептомицин является в настоящее время одним из нанболее употребляемых противотуберкулезных препаратов. Наряду с хорошими результатами лечения применение его вызывает иногда нарушения функций макроорганизма, обусловленные токсичностью антибиотика. Привыкание туберкулезных бацилл к стрептомицину, а также токсические явления, вызываемые антибнотнком, в некоторых случаях ограничивают возможности применения этого препарата. По данным многих авторов (Н. А. Васнльев, 1949; А. Е. Рабухин и соавт., 1949; J. R. Bignall и соавт., 1951; K. Graf, 1951; И. С. Шейнман, 1953; М. Л. Зиньков, 1954; Я. Ю. Попелянский, 1954 и др.), стрептомицин поражает главным образом восьмую пару черепномозговых нервов. Кохлеовестибулярные расстройства получены под влиянием стрептомицина и в опытах на животных (Г. А. Свинкина, 1950; Р. А. Вейс, 1952).

Қак правило, эти расстройства являются стойкими и сохраняются в течение длительного времени (отдельные больные прослежены до 3 лет) (Н. А. Васильев, 1949; 3. С. Бененсон, 1951; R. О. Kanada и соавт., 1951; Я. Ю. Попелянский, 1954 и др.).

Значительно реже при применении стрептомицина поражаются другие отделы нервной системы. Отчетливые реакции со стороны центральной нервной системы на. блюдаются после введения антибиотика в спинномозговой канал (А. Е. Рабухин и соавт., 1949 и др.). В литературе упоминаются отдельные случаи возникновения во время лечения этим препаратом общего паралича (P. L. Amiotti, 1953), эпилептических припадков с общими судорогами и потерей сознания (Ю. Н. Сахаров, 1955), энцефалопатии (J. R. Edge, 1951). И. Э. Габер и Г. С. Кан (1953) в опытах на животных показали, что большие дозы стрептомицина угнетают рефлексы хемороцепторов.

Несмотря на широкое применение антибиотика и наблюдаемые при этом нейротоксические расстройства, в литературе полностью отсутствуют работы, посвященные изучению влияния стрептомицина на высшую нервную деятельность. Между тем знание этой стороны действия антибиотика имеет большое значение. Исходя из вышензложенного, мы исследовали влияние стрептомицина на высшую нервную деятельность белых мышей.

\section{Методика}

Оборонительные условные рефлексы у здоровых белых мышей вырабатывались в двойной камере по методу И. С. Александрова и М. П. Цнбиной (1947). В качестве безусловного раздражителя применялся электрический ток напряжением 20 вольт. Условным раздражителем служили удары метронома (120 ударов в минуту) в течение 10 секунд. Выработка условного рефлекса производилась ежедневно, за исключением выходных дней. Условный раздражитель давался в опыте с интервалами в 50 секунд и при отсутствии условного рефлекса подкреплялся электрическим током. Условный рефлекс считался прочным, если хотя бы в течение 3 дней подряд у мыши ежедневно наблюдалось по 4-5 положительных от- 
ветов на условный раздражитель. В опытах регистрировались число положительных реакций на условный раздражитель, их латентный период, а также время условного и безусловного рефлекса. Показателем общего состояния мышей служил их вес.

После 30-дневной выработки у 16 мышей из 28 образовался сравнительно стойкий условный рефлекс. Эти 16 животных были разделены на 2 группы, причем в каждую из групп подбирались мыши с одинаковым числом положительных ответов на условный раздражитель. У мышей контрольной группы устойчивый условный рефлекс был получен в среднем на 19 день, а в подопытной - на 18. С 31 по 48 день подопытным животным за час до проверки у них условного рефлекса вводилось подкожно по 3000 ед. стрептомицина* в 0,5 мл физиологического раствора, что составляло 105-140 ед. антибиотика на 1 г веса тела. Қонтрольные животные получали соответствующее количество физиологического раствор,а, вводимого тем же путем.

\section{Результаты опытов}

Қак видно из рис. 1, среднее число положительных ответов на условный раздражитель у подопытных мышей, получавших в течение 3 недель стрептомицин в дозах 105-140 ед/г, заметно не изменялось.

В указанном промежутке времени у некоторых подопытных и контрольных животных отмечались незначительное удлинение латентного периода и увеличение времени условного и безусловного рефлексов. В подопытной группе мышей эти изменения были выражены несколько сильнее.

Так как стрептомицин в дозах 105-140 ед/г не вызвал убедительных изменений со стороны оборонительного рефлекса, то в дальнейшем, с 49 по 54 день, дозы антибиотика были увеличены до 5600 ед. на животное $(215-260$ ед/г).

Вначале исследование оборонительного рефлекса, как и раньше, проводилось через 1 час после введения стрептомицина. Однако уже в первый день введения таких доз антибиотика у некоторых животных были отмечены изменения поведения: отдельные мыши становились вялыми, мало подвижными, у них наблюдалось учащение дыхания. Эти нарушения были выражены уже через 40 минут после введения стрептомицина. Через час же после инъекции антибиотика животные выглядели нормально н оборонительный рефлекс находился в пределах нормы. Поэтому в дальнейшем, начиная с 51 дня, исследование оборонительното рефлекса проводилось не через час, а через 40 минут после введения стрептомицина.

Введение стрептомицина в дозах 5600 ед. на мышь вызывало у большинства животных выраженное уменьшение количества положительных ответов на условный раздражитель (рис. 1). У большинства подопытных мышей имело место удлинение латентного периода условного рефлекса. В тех случаях, когда наблюдалось уменьшение количества положительных ответов, время безусловного рефлекса либо оставалось в пределах нормы, либо заметно удлинялось. У некоторых мышей, на которые стрептомицин оказывал наиболее выраженное токсическое действие, наблюдалось полное отсутствие ответов как на условный, так и на безусловный раздражитель. У трех мышей, у которых имелись изменения со стороны условного и безусловного рефлексов, один раз наблюдалось расстройство равновесия.

* По данным Р. О. Драбкиной и Е. П. Синельниковой (1951), эта доза антибнотнка является терапевтической для белых мышей при экспериментальном туберкулезе. 
После 6-дневного введения больших доз стрептомицина мышам с 55 по 60 день был предоставлен полный отдых, а затем в течение недели исследовались условные рефлексы. При этом было установлено, что за время отдыха у подопытных животных произошло полное восстановление условнорефлекторной деятельности (рис. 1, 61-66 дни).

Поскольку одна из задач исследования заключалась в установлении пороповых доз стрептомицина, вызывающих отчетливые изменения со стороны условнорефлекторной деятельности у белых мышей, в течение следующей недели (с 67 по 72 день) изучалось действие антибиотика в дозах 200 ед. на 1 г веса мыши. Как видно из рис. 1, эти дозы стрептомицина не оказали заметного

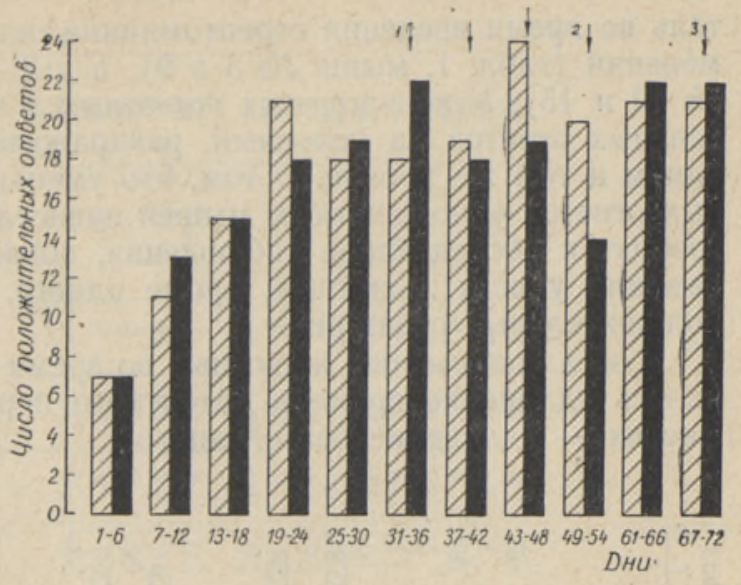

Р и с. 1. Среднее число положительных ответов на 1 мышь по неделям опыта (первая серия).

WI//. Контрольные мыши.

—. Подопытные мыши.

$1 \downarrow 3000$ ед. стрептомицина на мышь (105-140 ед. на 1 г веса тела мыши).

" $\downarrow 5600$ ед. стрептомицина на мышь (215-260 ед. на $1 \mathrm{r}$ веса тела мыши).

${ }^{\pi} \downarrow 200$ ед. стрептомицина на 1 г веса тела мыши.

влияния на число положительных условнорефлекторных реакций. Не наблюдалось также заметных изменений со стороны времени латентного периода и времени условного и безусловного рефлексов. Таким образом, стрептомицин в дозах 200 ед/г в условиях даннопо опыта не вызвал у белых мышей заметных изменений со стороны условнорефлекторной деятельности.

В этом опыте действие антибиотика в дозах 200 ед/г исследовалось после длительного введения других доз стрептомицина, что, естественно, могло отразиться на чувствительности организма животных к данному препарату. Необходимо также учесть и тот факт, что стрептомицин в дозах 200 ед/г вводился животным всего в течение одной недели. Поэтому в следующей серии опытов было изучено влияние длительного введения антибиотика в дозах 200 ед/г на условнорефлекторную деятельность белых мышей. После 30 дней выработки условного рефлекса животные были разделены на 2 группы (10 мышей подопытных и 5 контрольных). У мышей контрольной группы устойчивый условный рефлекс был получен в среднем к 20 дню, у подопытных животных - к 21 дню. Антибиотик вводился мышам подкожно в течение 5 недель (с 31 по 60 день) в дозах 200 ед/г. Контрольным животным тем же путем вводился физиологический раствор.

Как видно из рис. 2, во время введения стрептомицина у большинства подопытных мышей в течение первых двух недель наблюдалось дальнейшее увеличение количества положительных ответов на условный раздражитель. Однако, начиная с третьей недели инъекций антибиотика, у ряда мышей кколичество положительных ответов стало уменьшаться. В дальнейшем нарушения условнорефлекторной деятельности закономерно' прогрессировали и распространялись, на большее количество животных. У 2 из 10 мышей число положительных ответов на условный раздражи- 
тель во время введения стрептомицина оставалось без существенных изменений (табл. 1, мыши № 3 и 9), а у 2 - заметно повысилось (мыши № 49 и 15). У контрольных животных в это время количество положительных ответов на условный раздражитель оставалось примерно на өдном и том же уровне. О том, что уменьшение количества положительных ответов у подопытных мышей зависело от действия стрептомицина, говорят и последующие наблюдения, показавшие, что отмена препарата вызвала у всех животных, кроме одного, отчетливое увеличение числа положительных реакций.

У всех подопытных животных во время введения стрептомицина отмечалось удлинение времени латентного периода условного рефлекса и у многих - удлинение безусловното.

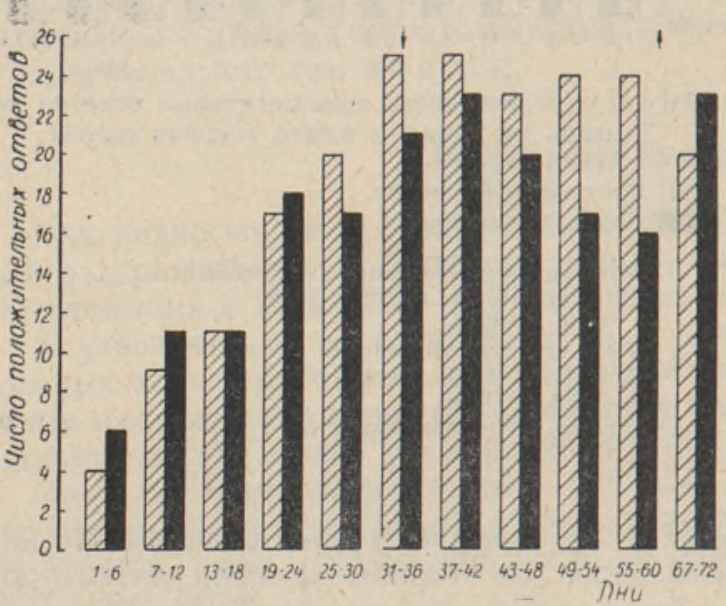

Р и с. 2. Среднее число положительных ответов на 1 мышь 10 неделям опыта (вторая серия).

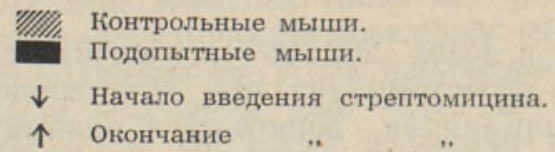

Расстройства равновесия најблюдались всего 10 раз у 7. мышей и, как правило, сопровождались нарушениями безусловного оборонительного рефлекса. Однако в большинстве опытов, где имело место удлинение безусловного оборонительного рефлекса, расстройств равновесия не наблюдалось. Интенсивность расстройств равновесия была различной: от легких пошатываний до полной атаксии. Нарушения со стороны безусловного рефлекса и равновесия чаще появлялись в течение последних двух недель инъекций стрептомицина, но постепенного углубления или учащения их в зависимости от общего количества введенного антибиотика замечено не было. В ряде случаев даже после самых тяжелых явле-

ний отравления в предыдущий день введение антибиотика в следующий раз не вызывало выраженных расстройств.

Расстройства нервной деятельности возникали через 40-50 минут (очень редко через 20 минут) после введения препарата, быстро прогрессировали и в течение 3 часов, как правило, проходили. Так, например, у мыши № 53 в одном из опытов (продолжительность опыта 5 минут) ответы на условный раздражитель отсутствовали, ответ на первый безусловный раздражитель последовал через 7 секунд, на второе и третье раздражения - через 20 секунд, на четвертое - через 15 , а на пятое раздражение мышь вовсе не реагировала. Заметных нарушений равновесия не наблюдалось.

Таким образом, длительное введение стрептомицина в дозах 200 ед/г вызывает у большинства мышей различные расстройства со стороны нервной деятельности, проявляющиеся в нарушениях условного и безусловного оборонительного рефлексов и нарушениях равновесия и дыхания. Наиболее часто при этом страдает условнорефлекторная деятельность, реже наблюдаются изменения со стороны безусловного рефлекса и еще 


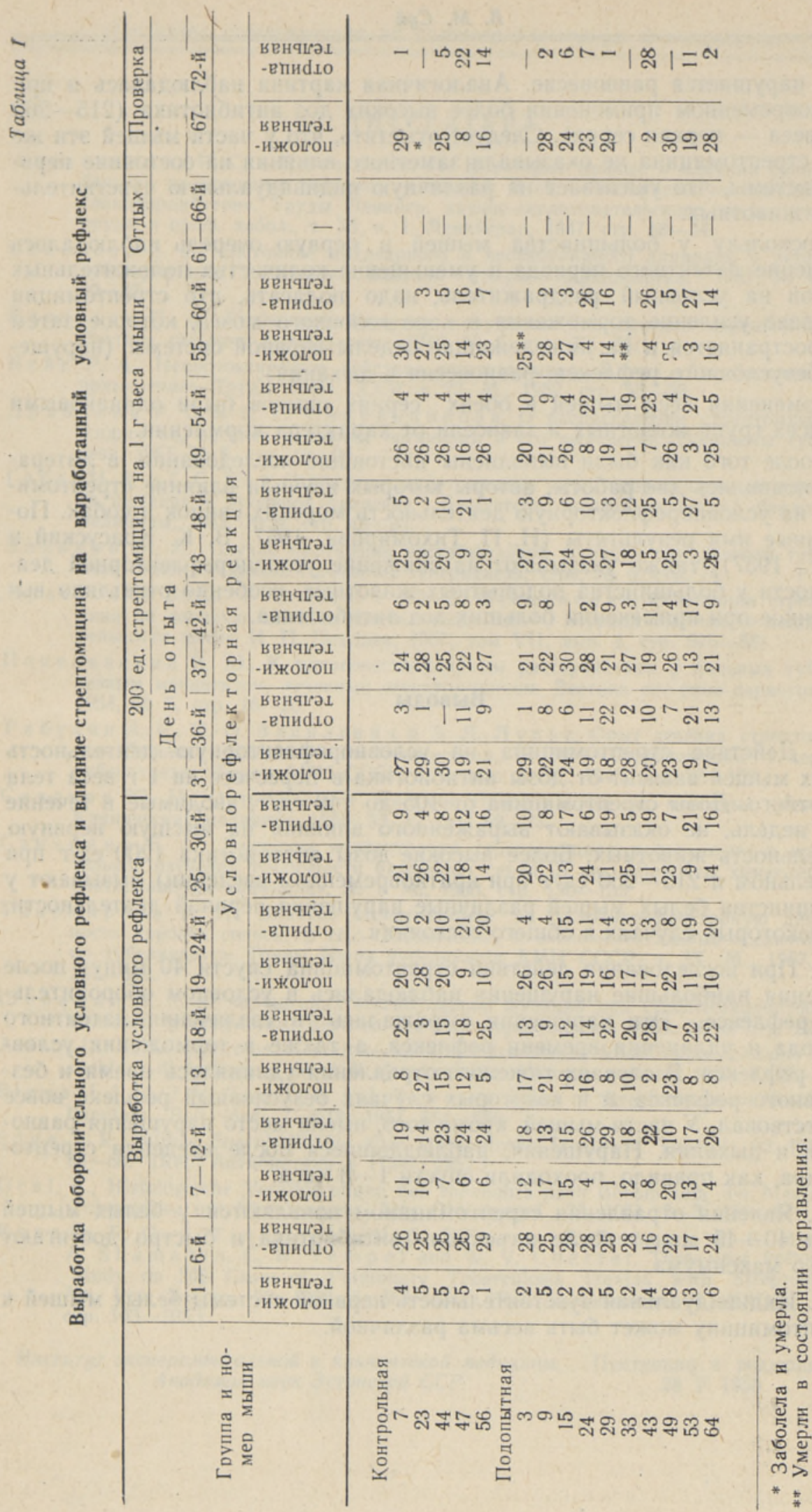


реже нарушается равновесие. Аналогичная картина наблюдалась и при кратковременном применении более высоких доз антибиотика (215-260 ед/г веса - первая серия). Следует отметить, что у части мышей эти же дозы стрептомицина не оказывали заметного влияния на состояние нервной системы, что указывает на различную индивидуальную чувствительность животных.

Поскольку у большинства мышей в первую очередь наблюдалось удлинение латентного периода и уменьшение количества положительных ответов на условный раздражитель, надо полагать, что стрептомицин вызывает усиление торможения в коре головного мозга, которое затем распространяется и на нижележащие отделы нервной системы (нарушения безусловного рефлекса, равновесия и дыхания).

Изменения веса мышей в обеих сериях опытов были одинаковыми для всех трупп животных и зависели от характера кормления.

После того как были выполнены настоящие исследования, в литературе появились две работы, авторы которых изучили влияние стрептомицина на условнорефлекторную деятельность морских свинок и собак. Полученные ими результаты (Н. П. Тихомирова, 1957; В. К. Красуский и соавт., 1957) также указывают на снижение условнорефлекторной деятельности у большинства подопытных животных, особенно отчетливо выраженное при применении больших доз антибиотика.

\section{Выводы}

1. Действие стрептомицина на условнорефлекторную деятельность белых мышей зависит от дозы антибиотика в пересчете на 1 г веса тела животного. Дозы стрептомицина от 105 до 140 ед/г, вводимые в течение трех недель, не оказывают выраженного влияния на высшую нервную деятельность животных. Более высокие дозы антибиотика (200 ед/г при длительном и 215-260 ед/г при кратковременном введении) вызывают у большинства белых мышей различные нарушения нервной деятельности, а в некоторых случаях и общего состояния.

2. При исследовании действия стрептомицина спустя 40 минут после введения наибольшие нарушения наблюдались в условном оборонительном рефлексе. Эти нарушения выражались в увеличении латентного периода и удлинении времени рефлекса, а также в торможении условного рефлекса. В случаях тяжелого отравления удлинялось время и безусловного рефлекса, а в некоторых случаях безусловный рефлекс вовсе отсутствовал. У части мышей, кроме того, имели место нарушения равновесия и дыхания. Нарушения, наблюдавшиеся после введения стрептомицина, как правило, проходили спустя $1-3$ часа.

3. Явления отравления стрептомицином появляются у белых мышей через 40-45 минут после инъекции антибиотика и быстро достигают своего максимума.

4. Индивидуальная чувствительность нервной системы белых мышей к стрептомицину может быть весьма различной. 


\section{Л ИТЕ РА Т У Р А}

Ал екс андров И. С. и Ци б и н а М. П., Некоторые данные о влиянии сланцевого бензина на условные рефлексы у мышей. В сб.: «Материалы по токсикологии сланцепродуктов». Труды Ленингр. научно-исследовательского ин-та гигиены труда и проф. забол., т. ХІ, ч. І. Ленинград, 1947, стр. 48-54.

Бен енсон 3. С., Состояние кохлеарного и вестибулярного аппарата у детей при туберкулезном менингите. Вестник ото-рино-ларингологии, 1951; № 4, стр. $29-37$.

В а си лье в Н. А., Кохлеовестибулярные нарушения при лечении стрептомицином. Вестник ото-рино-ларингологии, 1949, № 5, стр. 33-38.

Ве й с Р. А., Невротоксическое действие стрептомицина, В кн.: «Антибиотики и их применение». Труды АМН СССР, т. 22. М., 1952, стр. 55-58.

Д р а 6 к и н а Р. О. и Е. П. С ин е льн и кова, О распределении стрептомицина в жидкостях, органах и тканях организма и его выделении. Проблемы туберкулеза, 1951, № 5 . стр. 13 -20.

Г а 6 е р И. Э. и Г. С. К а н, О влиянии стрептомицина на интерорецептивные рефлексы, на дыхание и кровяное давление. Бюллетеңь экспериментальной биологии и медицины, 1953, № 9, стр. 48-53.

3 и н ь ко в М. Л., Случай нарушения вестибюларной функции при лечении туберкулеза стрептомицином. Проблемы туберкулеза, 1954, №6, стр. 74.

К р а су ски й В. К., Г. С. К ан и. Ю. В. С чен сн ович, О влиянии стрептомицина на высшую непвную деятельность собак. Журнал высшей непвной деятельности имени И. П. Павлова, 1957, том VII, вып. 4, стр. 575-581.

Попелян к и й Я. Ю., К кохлеовестибулярным расстройствам у больных туберкулезным менингитом, леченных стрептомицином. Вестник ото-рино-ларингологии, 1954, № 5, стр. $16-20$.

Р а бухин А. Е., Н. О. В а силеви ч и 3. Л. Лурье, Опыт лечения стрептомицином больных туберкилехным менингитом. В сб.: «Стрептомицнн в терапии туберкулеза». Труды АМН СССР, т. 2, вып. 5. М., 1949, стр. 85-103.

С аха ров Ю. Н., О токсическпм лействии стпептпмицина на мозговые оболочки. Клиническая медицина, $1955,33,12$, стр. $69-73$.

С в ин ки н а Г. А., Динамика концентрации стрептомицина в организме и сравнительное изучение токсичности различных серий. В кн.: «Вопросы химиотерапии бактернальных инфекций», №1. М., 1950, стр. 130-135.

Тихоми ров а Н. П., Влияние стрептомицина на условнорефлекторную деятельность морских свинок. В сб.: «Клинические и экспепиментальные исслепования по туберкулезу». Труды Ин-та туберкулеза АМН СССР, т. IX. M., 1957, стр. $301-312$.

Ше й н м а н И. С.. О нарушениях вестибулярной функции при стрептомицинотерапии больных туберкулезом. Вестник ото-рино-ларингологии, 1953, № 6, стр. 22-26.

A miotti. P. L.. Sindrome di sezione midollare transversa totale depo iniczione endorachidea di fortissime do si di streptomicina. Minerva pediatr., 1953, 5, $58-60$.

B ig n a I I, J. R., J. V. G roft o n. J. A. Th o mas. Effect of Streptomycin on Vestibular Function. Brit. Med., 7, 4706, 1951, $554-556$.

Edg e, J. R.. Diffuse Eneyphalipathy after Strentomycin Treatment. Tubercle, 32, 1951, 1, 58-60. (Ref.; Антибиотики 4 (130), 1952.)

Graf, K., Histologische Veränderungen des Innenohrs nach Behandlung dor Meningitis Tuberculosa mit Streptomycin. Acta Otolaryngol., 39, 1951, 2-3, 121-131.

Kanada, R. O., S. T. Allinson, N. D. D'Esodo. E. Dunner, R. E. Mover, A. Sh a ma ki n, C. W. Tempel and W. V. Charter, Three-year Follow-up Study on 202 Cases of Pulmonary Tuberculosis Treated with Streptomycin. Am. Rev. Tuberc., 62, 1950, 6, 563-571. (Ref.: Антибиотики 3 (XXIII), 1951, стр. 103-105.)

Институт экспериментальной и клинической медицины Академии наук Эстонской ССР

Поступила в редакцию 28 V 1958 


\title{
STREPTOMUTSIINI MOJUST VALGETE HIIRTE TINGITUD REFLEKTOORSELE TEGEVUSELE
}

\author{
V. Sui
}

\section{Resümee}

Streptomütsiini kliinilisel kasutamisel kàasuvad tema spetsiffilise ravitoimega sageli närvisüsteemi toksilise kahjustuse nähud. Eksperimentaalsed andmed streptomütsiini mõju kohta kõrgemale närvitegevusele on vähesed, olgugi et antibiootikumi toime see külg on olulise tähtsusega tema toime iseloomustamiseks mikroorganismisse. Uurides käesoleva töö käigus Aleksandrovi ja Tsibina poolt väljatöötatud kaitserefleksi tekitamise meetodiga streptomütsiini toimet nähtus, et see sôltub kasutatud annusest, arvestatud $1 \mathrm{~g}$ hiire kehakaalu kohta. Annused 105-140 ühikut manustatuna 3 nädala vältel ei avaldanud olulist mõju loomade kōrgemale närvitegevusele. Suuremad antibiootikumi annused (200 ühikut 5 nädala ja 250 ühikut 7 nädala kestel) kutsusid enamikul valgetel hiirtel esile mitmesuguseid närvitegevuse, mōnel juhul ka üldseisundi häireid. Streptomütsiini toime uurimisel 40 minutit pärast süstimist selgus, et kōige enam häireid esines tingitud refleksis. Need avaldusid tingitud refleksi aja ning latentsusperioodi pikenemises ja tingitud refleksi pidurdumises. Raskema mürgistuse juhtudel pikenes ka tingimatu refleksi aeg ja mõnel juhul tingimatu refleks puudus. Väikesel osal hiirtel esinesid peale selle veel tasakaalu- ja hingamishäired. Mürgistusnähte täheldati valgetel hiirtel $40-45$ minutit pärast antibiootikumi süstimist. Mainitud nähud saavutasid kiiresti (minutite vältel) maksimumi ja möödusid $1-3$ tunni jooksul. Katseis ilmnes, et valgete hiirte närvisüsteemi individuaalne tundlikkus streptomütsiini suhtes vôib olla väga erinev.

Eesti NSV Teaduste Akadeemia

Eksperimentaalse ja Kliinilise Meditsiini Instituut

Saabus toimetusse

28. V 1958

\section{ABOUT THE EFFECT OF STREPTOMYCIN ON THE CONDITIONED REFLEX ACTIVITY OF WHITE MICE}

\section{Sui}

\section{Summary}

In the clinical use of streptomycin, along with the specific therapeutic effect, toxic damages of the nervous system appear in some cases.

From this experimental work it is evident that the effect of streptomycin depends on the dose used, calculated per gram to the body weight of a mouse.

105-140 units of streptomycin given for a period of 3 weeks did not produce any special effect on the higher nervous activity of the mice. Increased doses of the antibiotic (200 units during 5 weeks or 250 units during 1 week being injected) brought about some damages of the nervous system to the majority of the white mice.

Those disarrangements appeared mostly in the prolongation of the period of latency of the conditioned reflexes and in the inhibition of the conditioned reflex action.

In cases of deeper intoxication the duration of the unconditioned reflex action was also prolonged and in some cases the unconditioned reflex was absent. Besides, a minor part of the mice suffered from disturbances of balance and breathing.

The signs of intoxication occurred $40-45 \mathrm{~min}$. after the injection and developed swiftly (during some minutes) to the maximum and disappeared after $1-3$ hours.

The tests showed that the nervous system of white mice has essentially dilferent sensibility to streptomycin.

Academy of Sciences of the Estonian S.S.R..

Institute of Experimental and Clinical Medicine

Received

May 28, 1958 